\title{
Laporan Kasus: Melanoma Maligna Intrakranial Primer
}

\author{
Andrea Valentino $^{1 *}$, Rijalun Arridho ${ }^{2}$
}

\begin{abstract}
Primary intracranial malignant melanoma is an extremely rare tumor. Most of the intracranial malignant melanoma are metastatic from skin. Diagnosis needs multidisciplinary workup to exclude metastatic melanoma. We are reporting a case of young girl with decrease consciousness and tetraplegia. CT scan revealed a solitary tumor mass in the brain. Histopathological examination and confirmed by immunohistochemistry showed that the type of tumor was intracranial primary malignant melanoma and by excluding metastatic melanoma. Tumor excision was performed in patient and adjuvant chemotherapy was given, but residual tumors were present multiple.
\end{abstract}

Keywords : intracranial, malignant melanoma, primary tumour

Melanoma merupakan tumor yang berasal dari melanosit yang dapat ditemukan pada lapisan basal epidermis kulit dan uvea. Melanosit juga ditemukan secara normal pada jaringan leptomeningeal dan parenkim otak. ${ }^{1}$ Melanoma intrakranial merupakan neoplasma yang berasal dari melanosit jaringan leptomeningeal. Kejadian melanoma intrakranial berkisar antara 0,07-0,17\% dari seluruh kasus tumor otak. Jenis melanoma intrakanial terdiri dari tiga kategori yaitu melanoma berdiferensiasi baik, melanoma intermediet dan melanoma maligna primer. Melanoma maligna intrakranial primer merupakan penyakit yang sangat jarang dan kejadiannya sekitar $1 \%$ dari seluruh kasus melanoma. ${ }^{2}$

\section{LAPORAN KASUS}

Seorang anak perempuan umur 9 tahun datang ke IGD RSUD Arifin Achmad dengan penurunan kesadaran dan kejang sejak 1 minggu sebelum masuk rumah sakit. Tangan serta kaki kanan dan kiri pasien lemah sejak 2 minggu sebelumnya. Pasien memiliki riwayat ensefalitis 6 bulan sebelumnya dengan gambaran normal pada CT-Scan kepala yang

\footnotetext{
* Corresponding author : dr_reano@yahoo.com

1 KJFD Bedah Fakultas Kedokteran Universitas Riau/ KSM Bedah RSUD Arifin Achmad Provinsi Riau. Pekanbaru

2 Fakultas Kedokteran Universitas Riau
}

dilakukan pada 26 Juni 2018 (Gambar 1a). Pada pemeriksaan fisik didapatkan kesadaran apatis dengan suhu tubuh $38,2^{\circ} \mathrm{C}$. Leher, ekstremitas atas dan bawah spastik. Hasil pemeriksaan laboratorium menunjukkan leukositosis ringan dengan hitung jenis leukosit dalam batas normal dan CRP nonreaktif. Saat di IGD RSUD Arifin Achmad, pasien didiagnosis dengan meningitis. Pasien diberikan obat fenitoin, seftriakson, amikasin, dexametason dan dirawat di PICU.

Pada pemeriksaan CT-scan tanpa kontras pada tanggal 14 Desember 2018 ditemukan gambaran lesi isodens berbentuk bulat berbatas tegas dengan ukuran 6,49x 5,12 x 5,60 cm dengan perifokal edem pada lobus frontal sinistra disertai pelebaran sistem ventrikel (Gambar 1b). Kesan pada gambaran CTScan yaitu terdapat tumor intra axial supratentorial pada lobus frontal sinistra disertai sistem ventrikel yang melebar (Gambar 1b). Dokter spesialis anak bagian neurologi mendiagnosis pasien dengan suspek astrositoma. Pasien dikonsultasikan ke dokter bedah saraf disertai dengan permintaan rawat bersama. Berdasarkan penilaian dokter bedah saraf, pasien didiagnosis dengan suspek PNET (Primitive NeuroEctodermal Tumor) lobus frontal sinistra, kemudian dilakukan operasi craniotomy tumor removal pada tanggal 15 Januari 2019. 
Diagnosis intraoperatif adalah melanoma maligna karena ditemukan massa tumor berwarna hitam dan menginfiltrasi jaringan sekitarnya (Gambar 2). Jaringan tumor kemudian diperiksa di Laboratorium Patologi Anatomi. Pemeriksaan histopatologi menunjukkan gambaran sel tumor pleomorfik dengan inti sel besar dan sitoplasma mengandung pigmen berwarna coklat kehitaman disertai jaringan nekrosis dan pendarahan. Berdasarkan morfologi sel tumor yang diperiksa, terdapat tiga kemungkinan diagnosis banding diantaranya: 1) melanoma maligna, 2) karsinoma pleksus khoroideus berpigmen, 3) papillary medulloblastoma berpigmen. Pewarnaan synaphtophysin menunjukkan hasil negatif, hal ini dapat menyingkirkan diagnosis banding karsinoma pleksus koroideus berpigmen dan papillary medulloblastoma berpigmen, sehingga diagnosis histopatologi pasien adalah melanoma maligna. ${ }^{3}$
Pemeriksaan imunohistokimia (IHC) menunjukkan hasil protein S-100 positif, hal ini sesuai dengan diagnosis melanoma maligna secara histopatologi. ${ }^{3}$ Satu minggu pascaoperasi kesadaran pasien membaik dan masih dalam kondisi tetraplegi. Satu bulan kemudian pasien diberikan kemoterapi adjuvan oleh dokter anak bagian onkologi. Obat kemoterapi yang diberikan adalah decarbazine. Pasien dijadwalkan kemoterapi setiap 21 hari. Pasca pemberian kemoterapi siklus pertama, pasien kembali datang ke IGD dengan penurunan kesadaran. Pemeriksaan CT-Scan kepala pada tanggal 30 Januari 2019 dengan kontras menunjukkan gambaran lesi hiperdens multipel intraserebral disertai pelebaran sistem ventrikel (Gambar 1c). Hal ini sesuai dengan kondisi tumor residif disertai hidrosefalus, kemudian dilakukan tindakan VP-shunt.

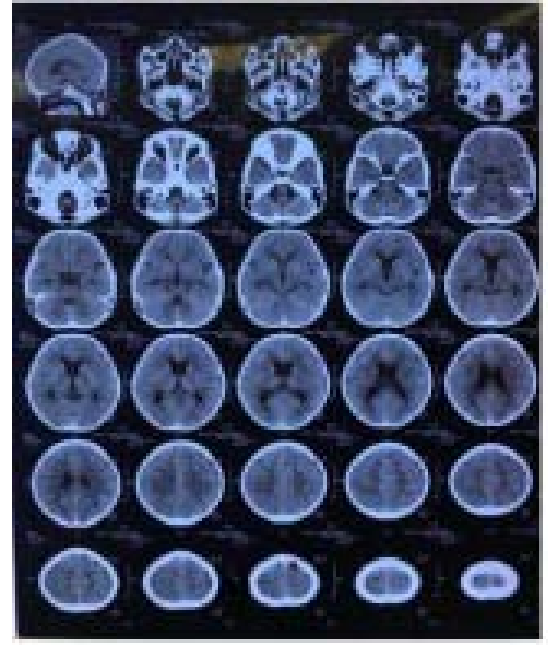

a)

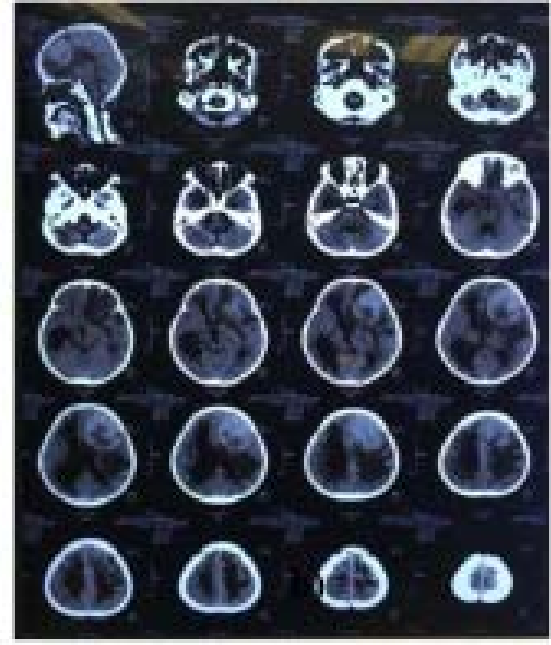

b)

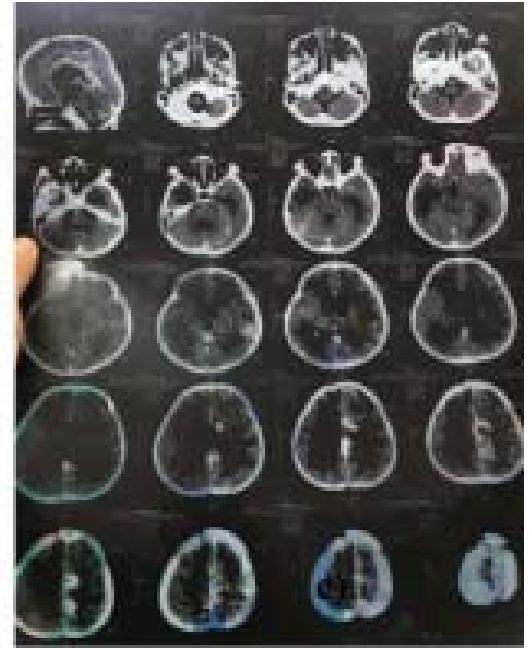

c)

Gambar 1. Gambaran CT-Scan kepala potongan aksial. a) Dilakukan pada 6 bulan sebelum diagnosis melanoma maligna (26 Juni 2018), kesan normal (tanpa kontras); b) Gambaran tumor intra-axial supratentorial pada lobus frontal sinistra disertai pelebaran sistem ventrikel (tanpa kontras) pada 14 Desemer 2018; c) Gambaran lesi hiperdens multipel intraserebral disertai pelebaran sistem ventrikel (dengan kontras) dilakukan paska operasi tanggal 30 Januari 2019 


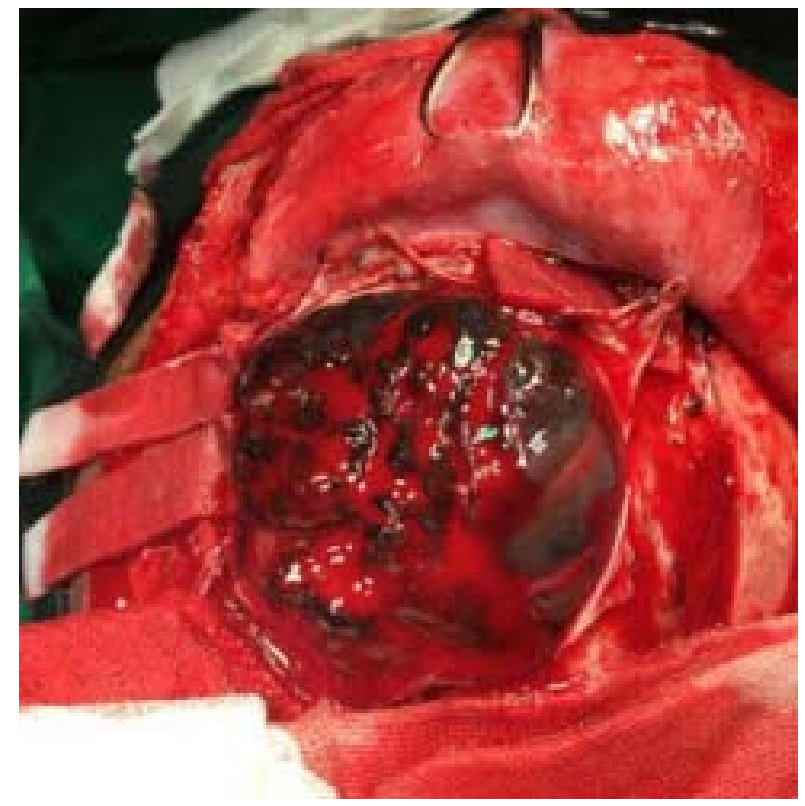

a)

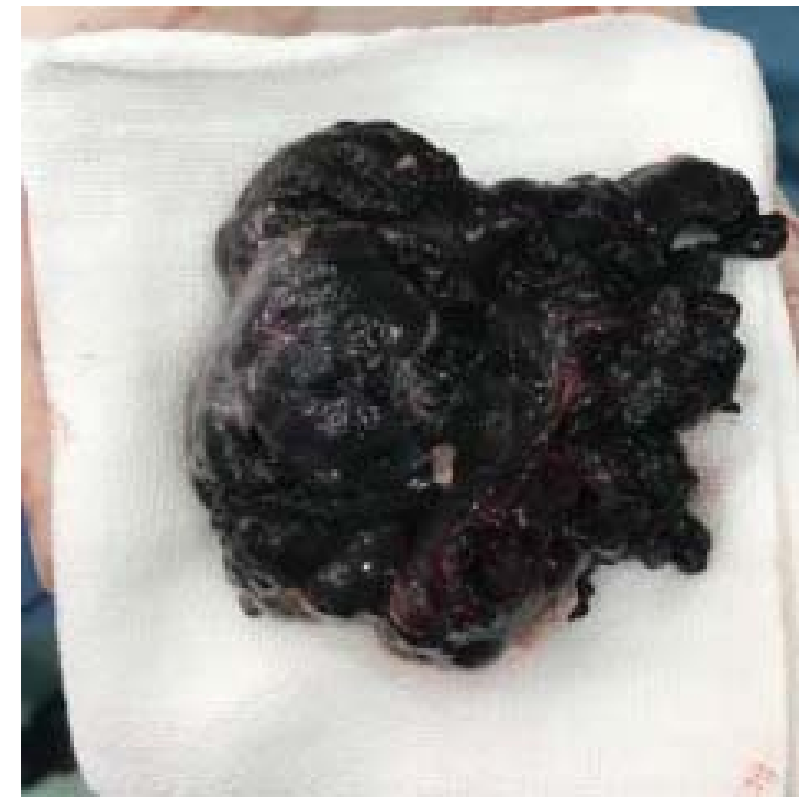

b)

Gambar 2. a) Gambar massa tumor intraoperatif; b) Gambaran makroskopik massa tumor, tampak massa jaringan tumor ireguler berwarna hitam.

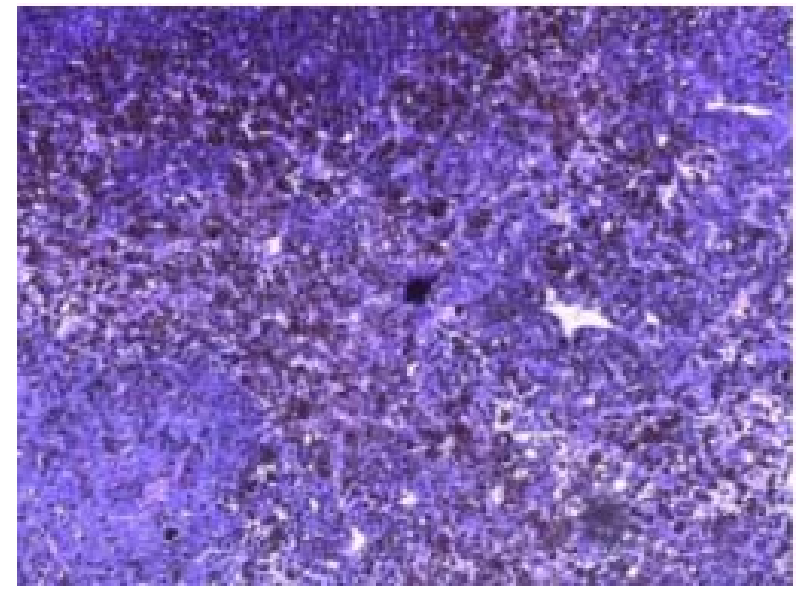

a)

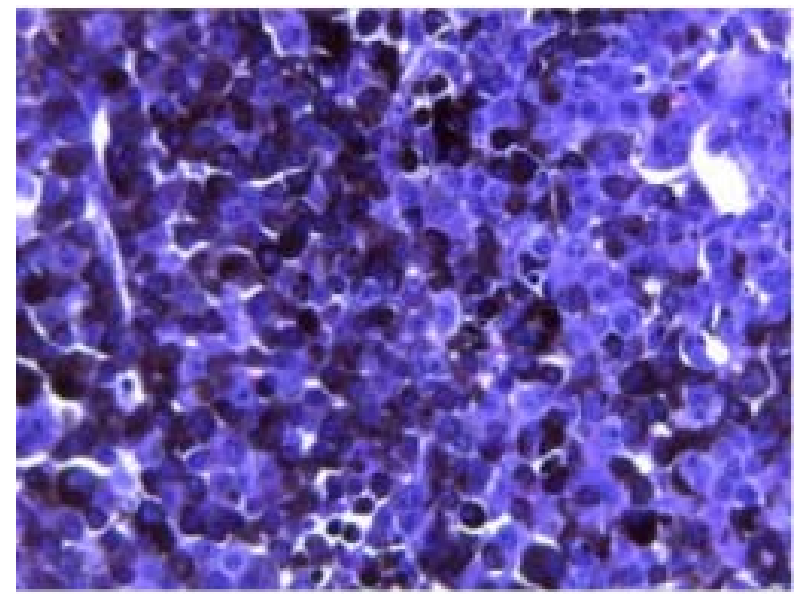

b)

Gambar 3. (a dan b) Gambaran mikroskopik jaringan dengan stroma mengandung massa tumor ganas yang sudah menginfiltrasi jaringan sekitarnya. Sel tumor berinti pleomorfik, dengan anak inti mencolok dan ditemukan sitoplasma mengandung pigmen berwarna tengguli. Tampak pula daerah perdarahan dan nekrosis.

\section{DISKUSI}

Melanoma intrakranial sebagian besar merupakan metastasis dari melanoma kulit. Diagnosis melanoma maligna intrakranial primer dapat ditegakkan dengan menyingkirkan adanya melanoma ekstrakranial yang bermetastasis ke otak. Diperlukan multidisiplin ilmu dari bagian dermatologi, optalmologi dan radiologi untuk menyingkirkan adanya melanoma primer di kulit dan uvea yang dapat metastasis ke otak. Pemeriksaan CT-Scan pada melanoma intrakranial tidak spesifik, demikian juga dengan pemeriksaan histopatologi maupun imunohistokimia tidak dapat membedakan atau hasil metastasis. ${ }^{3,4}$ Salah satu tanda keganasan pada 
kasus ini yaitu pertumbuhan tumor yang cepat. ${ }^{4}$ Berdasarkan pemeriksaan CT-Scan kepala tanpa kontras pada dua waktu yang berbeda, massa tumor dari awalnya tidak dapat terlihat hingga pada 6 bulan setelahnya memenuhi lobus frontal hemisfer kiri otak. Tanda keganasan lainnya yaitu pada saat operasi ditemukan massa tumor soliter berwarna hitam dan menginfiltrasi jaringan sekitar (Gambar 2). Protein S-100 merupakan tumor marker lini pertama pada melanoma maligna dengan sensitivitas $96-99 \%$ dan spesifitas $75-87 \%$. Pemeriksaan IHC protein S-100 pada kasus ini menunjukkan hasil positif. ${ }^{5}$ Gambaran histopatologi melalui gambaran mikroskopik jaringan dan pewarnaan synaphtophysin membuktikan bahwa diagnosis pasien adalah melanoma maligna. Terapi untuk tumor ganas otak soliter yang dianjurkan adalah operasi reseksi tumor dilanjutkan dengan radioterapi (whole brain radiation therapy/ WBRT). Jika tumor berukuran kecil dan lokasinya dalam, maka terapi yang dianjurkan adalah stereotactic radiosurgery/ SRS dilanjutkan dengan WBRT. Pada pasien ini dilakukan reseksi total tumor dilanjutkan dengan kemoterapi. satu bulan kemudian dilakukan CT-Scan dengan kontras dan ditemukan tumor residif multipel. Berdasarkan NCCN 2019 disebutkan bahwa kemoterapi merupakan pilihan jika tumor multipel dan tidak dapat dilakukan WBRT maupun SRS, karena obat kemoterapi sulit untuk menembus sawar darah otak. ${ }^{6}$

\section{DAFTAR PUSTAKA}

1. Tang K, Kong X, Mao G, Qiu M, Zhu H, Zhou L et al. Primary cerebral malignant melanoma; A case report with literature review. Medicine. 2017;96(4):1-6.

2. Ma Y, Gui Q, Lang S. Intracranial malignant melanoma: A report of 7 cases. Oncology Letters. 2015;10:2171-5.

3. Mondal S, Pradhan R, Pal S, Bhattacharya S, Banerjee, Bhattacharya D. Primary intracranial malignant melanoma in an adolescent girl: A Case report. Clin Cancer Invest J. 2016;5(6):551-3

4. Vijayalaxmi V, Suranagi, Maste P, Malur PR. Primary intracranial malignant melanoma: A rare with literature review. Asian Jornal of Neurosurgery. 2015;10:(1):39-41.

5. Biernacka A, Linos KD, Liu X. A case of S-100 negative melanoma: A diagnostic pitfall in the workup of a poorly differentiated metastatic tumor of unknown origin. Cytojournal. 2016;13:(21):711.

6. National Comprehensive Cencer Network. Central nervous system cencer; NCCN clinical practice guideline in oncology. 2019. 